Krzysztof Szczygielski

\title{
Konkubinat w przedkodeksowym prawie kanonicznym Kościoła katolickiego
}

\begin{abstract}
Summary
The question of concubinage was very often mentioned in the sources and works of the pre-Code law of the Catholic Church. Living in a public concubinage was treated as manifest grave sin, which was condemned and punished by canonical penalties. The provisions of the Council of Trent (1545-1563) mentioned the problem of concubinage in the context of proper application of sanctions. If there were any doubts, the Sacred Congregation of the Council was competent to resolve them. All the other problems related to the issue were solved by the Roman Congregations, such as the Sacred Congregation of the Universal Inquisition, the Sacred Congregation for the Propagation of the Faith and the Sacred Congregation of Bishops and Regulars. After Tridentinum, Popes treated the problem of concubinage with utmost attention. Apostolical constitutions and encyclicals were published, in which they informed the Christ's faithful about the consequences of living in such extra-marital union. These explanations played an important role in the uniform application of canon law. Many of them were subsequently included into Code of Canon Law, which was promulgated in 1917.
\end{abstract}

Celem niniejszego opracowania jest krótkie przedstawienie problematyki konkubinatu w świetle źródeł i nauki przedkodeksowego prawa kanonicznego. Przedmiotem badań objęte zostały regulacje prawne wydane po zakończeniu obrad soboru trydenckiego (1545-1563) ${ }^{1}$ aż do momentu promulgacji przez

${ }^{1} \mathrm{Na}$ temat wcześniejszych regulacji prawa kanonicznego odnoszących się do konkubinatu zob. m.in. W. Jaskulski, Konkubinat wedle praw karnych kościelnych $i$ świeckich, „Przegląd Kościelny” 1896, nr 18, s. 729-737; J. F. Gallagher, The Matrimonial Impediment of Public Propriety, Washington 1952, s. 102-114; J. A. Brundage, Concubinage and Marriage in Medieval Canon Law, "Journal of Medieval History" 1975, nr 1, s. 1-17; idem, Law, Sex and Christian Society in Medieval Europe, Chicago 1990, passim; K. Szczygielski, Problematyka konkubinatu w uchwałach soborów powszechnych XII-XVI wieku, „Miscellanea historico-iuridica” 2006, t. 4, s. 41-57. 
papieża Benedykta XV (1914-1922) bullą Providentissima Mater Ecclesia z dnia 27 maja 1917 r. Kodeksu Prawa Kanonicznego ${ }^{2}$. Analizie poddano przede wszystkim liczne wyjaśnienia kongregacji rzymskich i papieży, odnoszące się do konkubinatu, jak również wypowiedzi wybitnych kanonistów, żyjących we wspomnianym okresie.

Powzięte na soborze trydenckim uchwały precyzowały sposoby walki Kościoła katolickiego ze zjawiskiem konkubinatu zarówno wśród wiernych świeckich, jak i członków stanu duchownego ${ }^{3}$. Papież Pius IV (1559-1565) zatwierdził bullą Benedictus Deus z dnia 26 stycznia 1564 r. postanowienia soborowe i zakazał jednocześnie osobom kościelnym z każdego zakonu, godności i stopnia, jak również świeckim, niezależnie od godności i posiadanej władzy, bez pozwolenia Stolicy Apostolskiej dokonywania jakichkolwiek prób komentowania, objaśniania i interpretacji dekretów soborowych ${ }^{4}$. Troska wspomnianego papieża o należyte wprowadzenie w życie ogłoszonych uchwał i czuwanie nad ich przestrzeganiem zaowocowała wydaniem motu proprio Alias nos nonnullas z dnia 2 sierpnia 1564 r., w którym ustanowił specjalną Kongregację dla Wykonywania i Przestrzegania reform Soboru Trydenckiego i innych (Sacra Congregatio super executione et observantia Sacri Concilii Tridentini et aliarum reformationum). Uprawnienia do autentycznego wyjaśniania dekretów soborowych otrzymała kongregacja dzięki papieżowi Piusowi V (1566-1572), co spowodowało zmianę dotychczasowej nazwy na Kongregację Kardynałów interpretujących Sobór Trydencki (Sacra Congregatio Cardinalium Concilii Tridentini Interpretum). Następnie papież Sykstus V (1585-1590), na mocy konstytucji Immensa aeterni Dei z 22 stycznia 1588 r. dokonał kolejnej zmiany nazwy na Kongregację dla Wykonywania i Interpretacji Soboru Trydenckiego (Sacra Congregatio pro executione et interpretatione Concilii Tridentini) zwaną w skrócie Kongregacją Soboru (Sacra Congregatio Concilii) $)^{5}$. Zachowane teksty źródłowe pokazują, iż przedmiot żywego zainteresowania powołanej przez Piusa

\footnotetext{
${ }^{2}$ Kodeks zaczął obowiązywać od 19 maja 1918 r. Zob. „Acta Apostolicae Sedis” 1917, nr 9, pars II.

${ }^{3}$ Postanowienia odnoszące się do wiernych świeckich żyjących w konkubinacie zgrupowane były w rozdziale 8 uchwalonym na XXIV sesji, zatytułowanym Concubinatus poenis gravissimis punitur. Natomiast regulacje dotyczące duchownych zamieszczone zostały w rozdziale 14 dekretu o reformie ogólnej (Praescribitur ratio procedendi in causis clericorum concubinariorum) uchwalonym podczas XXV sesji soboru.

${ }^{4}$ Bulla sanctissimi domini nostri Pii quarti pontifici maximi super confirmatione sacri oecumenici concilii Tridentini, [w:] Dokumenty Soborów Powszechnych, oprac. A. Baron, H. Pietras, t. 4, Kraków 2005 , s. $860-866$.

${ }^{5}$ Nazwa ta funkcjonowała do chwili wydania konstytucji Regimini Ecclesiae uniwersae z 15 sierpnia 1967 r. w czasie pontyfikatu Pawła VI (1963-1978), która zmieniła ją na Kongregację do Spraw Duchowieństwa (Sacra Congregatio pro Clericis). Szerzej na temat historii i kompetencji tej kongregacji zob. E. Sztafrowski, Kuria Rzymska. Studium historyczno-kanoniczne, Warszawa 1981, s. 120-131.
} 
IV kongregacji stanowiła między innymi problematyka związana ze zjawiskiem konkubinatu zarówno wśród duchownych, jak i świeckich. Podkreślić trzeba jednak wyraźnie fakt, że $\mathrm{w}$ omawianym okresie prawno-kanonicznymi skutkami pozostawania $\mathrm{w}$ tym pozamałżeńskim związku zajmowały się również, w granicach przysługujących im kompetencji, inne kongregacje kurii rzymskiej.

\section{Wyjaśnienia odnoszące się do duchownych}

Pierwszym dokumentem poruszającym problematykę konkubinatu osób stanu duchownego, jaki został opublikowany po soborze trydenckim, była konstytucja Piusa V Cum primum ${ }^{6}$ z 1 kwietnia 1566 r., w której papież przypominał o karach grożących duchownym dopuszczającym się konkubinatu. Podobne zalecenia zawierała również konstytucja Apostolici ministerii ${ }^{7}$ papieża Innocentego XIII (1721-1724) z 23 maja 1723 r. Wspomniany papież zachęcał w niej biskupów, aby bez pobłażliwości stosowali sankcje karne ustanowione przez wcześniejszych papieży oraz sobory przeciwko kapłanom winnym popełniania różnych przestępstw. Wśród wymienionych znajdowali się także duchowni trwający w konkubinacie.

Następca Innocentego XIII na Stolicy Piotrowej, papież Benedykt XIII (1724-1730), w konstytucji In supremo ${ }^{8}$ z 23 września 1724 r. potwierdził stanowisko swojego poprzednika i przynaglił do aplikacji instrukcji zawartych w jego konstytucji Apostolici ministerii. Swoją zdecydowaną postawę w walce $\mathrm{z}$ konkubinatem duchownych Benedykt XIII wyraził również w wydanej w dniu 27 marca 1726 r. konstytucji Pastoralis officii ${ }^{9}$. Przywołane przykłady powtarzających się nacisków i ponagleń pokazują, iż biskupi nie zawsze wykazywali się wymaganą od nich w takich przypadkach stanowczością i konsekwencją w działaniu. Stąd też liczne próby poprawy tego stanu rzeczy podejmowane ze strony najwyższych zwierzchników Kościoła.

${ }^{6}$ Pius V, const. Cum primum, 1 kwietnia 1566 r., [w:] Codicis Iuris Canonici Fontes, t. 1-6, P. Gasparri (ed.); t. 7-9, I. Seredi (ed.), Romae 1923-1939 (dalej: Fontes). Monemus praeterea omnes locorum Ordinarios, et in virtute sanctae obedientiae eis praecipimus, ut statuta Tridentini Concilii contra concubinarios, tam clericos, quam laicos edita, districte faciant observari, reddituri Deo, ac Nobis, si id omiserint, rationem. Fontes, t. 1, n. $111 \$ 12$, s. 200.

${ }^{7}$ Zob. Innocentius XIII, const. Apostolici ministerii, 23 maja 1723 r., [w:] Fontes, t. 1, n. $280 \leqq 8$ s. 585.

${ }^{8}$ Zob. Benedictus XIII, const. In supremo, 23 września 1724 r., [w:] Fontes, t. 1, n. $283 \$$ 6, s. 601.

${ }^{9}$ Zob. Benedictus XIII, const. Pastoralis officii, 27 marca 1726 r., [w:] Fontes, t. 1, n. $292 \S 3$, s. 634. 
Kolejną wzmiankę $\mathrm{w}$ potrydenckich źródłach powszechnego prawa kanonicznego, poruszającą problem walki z konkubinatem duchownych, odnaleźć można w konstytucji Ad militantis ${ }^{10}$ Benedykta XIV (1740-1758) z 30 marca $1742 \mathrm{r}$. Zostały w niej taksatywnie wyliczone kategorie przestępstw stosownie do uchwał soboru trydenckiego, zaskarżenie których w drodze postępowania odwoławczego przez osoby skazane nie powodowało skutku zawieszającego. Wspomniana konstytucja postanawiała między innymi, że wniesienie apelacji od cenzur, jak również innych zarządzeń, wydanych przeciwko konkubentom, a przede wszystkim duchownym utrzymującym $\mathrm{w}$ domu lub poza nim podejrzane kobiety, nie wstrzymywało wykonania nałożonych na nich uprzednio kar. Dotknięty wyrokiem mógł zatem apelować tylko cum effectu devolutivo ${ }^{11}$.

Według opinii wyrażonej przez E. Jombarta ${ }^{12}$ mniejsza liczba dokumentów z okresu potrydenckiego, odnoszących się do kwestii konkubinatu osób stanu duchownego, jakie można znaleźć w oficjalnych zbiorach źródeł prawa kanonicznego, wskazuje na to, że począwszy od XVIII stulecia nastąpiła znaczna poprawa obyczajów wśród ówczesnego duchowieństwa, co w konsekwencji spowodowało ściślejsze przestrzeganie dyscypliny kościelnej przez duchownych.

Byłoby jednak wielkim uproszczeniem twierdzić, że nie zdarzały się w owym okresie żadne przypadki pożycia w konkubinacie przez duchownych. Istnieje co najmniej kilka dekretów Stolicy Apostolskiej, w których zapadły decyzje w sprawach duchownych pozostających w stosunkach konkubenckich. Można jednak przypuszczać, że takich przypadków było znacznie więcej, ponieważ nie wszystkie sprawy karne czy sporne trafiały do rozpoznania przez właściwe kongregacje rzymskie czy trybunały Stolicy Apostolskiej.

Odnotować należy w szczególności dekret Spoletana ${ }^{13}$ wydany przez Kongregację Soboru w dniu 7 lipca 1860 r. Wspomniana kongregacja potwierdziła w tymże dekrecie słuszność decyzji arcybiskupa ze Spolete, który nałożył karę suspensy na jednego $\mathrm{z}$ podległych mu proboszczów z powodu utrzymywania przez niego zażyłych stosunków ze służącą, która nie miała odpowiedniego wieku wymaganego przez statuty synodalne (ukończony 40. rok życia). Odwołanie się przez proboszcza do Rzymu okazało się bezskuteczne, ponieważ

${ }^{10}$ Zob. Benedictus XIV, const. Ad militantis, 30 marca 1742 r., [w:] Fontes, t. 1, n. $326 \S 25$ : Item a Censuris, aut aliis provisionibus contra Concubinarios, et praesertim Clericos etiam retinentes domi, aut extra, Mulieres suspectas; iuxtaa prascriptum Sacri Concili sess. 24 de reform. matrim., cap. 8, et sess. 25, de reform., caap. 14 , s. 728.

${ }^{11}$ I. Grabowski, Prawne środki w procesie kanonicznym. Studyum historyczno-prawne, Lwów 1913, s. $106-110$ oraz 128.

${ }^{12}$ E. Jombart, Concubinage, [w:] Dictionnaire de Droit Canonique, t. 3, Paris 1953, col. 1517-1518.

${ }^{13}$ Zob. S.C.C., Spoletana, 7 lipca 1860 r., [w:] Fontes, t. 6, n. 4184, s. 482-484. 
udowodniono mu przebywanie $\mathrm{z}$ tą kobietą dniem i nocą (cum ea solum diu noctuque inhabitare).

Podobny zarzut postawiono proboszczowi w diecezji Bamberg, który to utrzymywał niewłaściwe relacje ze służącą, mającą nieślubne dziecko. Fakt ten wywoływał zgorszenie wśród wspólnoty wiernych i stał się przyczyną wszczęcia przez arcybiskupa postępowania przeciwko duchownemu zmierzającego do wymierzenia mu kary suspensy. Pomimo to, iż arcybiskup wykorzystał wszystkie środki zaradcze, wymagane przepisami prawa kanonicznego, to wspomniany proboszcz nie zastosował się do nich i nie oddalił od siebie owej kobiety. Po stwierdzeniu uporu, arcybiskup zdecydował się ukarać go suspensą. Z kolei proboszcz, chcąc uniknąć skutków kanonicznych nałożonej na niego kary, odwołał się do Kongregacji Biskupów i Zakonników (Sacra Congregatio Episcoporum et Regularium) ${ }^{14}$. Kongregacja ta po rozpoznaniu sprawy w dniu 17 sierpnia 1883 r. $^{15}$ potwierdziła zasadność decyzji podjętej przez kurię arcybiskupią. W wydanym dekrecie orzekła ostatecznie, że duchownego należało przenieść do innej parafii i ponadto winien on natychmiast zerwać relacje łączące go $\mathrm{z}$ podejrzaną służącą. W uzasadnieniu podjętej decyzji kongregacja przywołała przepisy zamieszczone w rozdziale 14 sesji XXV soboru trydenckiego, które regulowały postępowanie z duchownymi pozostającymi w konkubinacie. Należy w tym miejscu dodać, że właśnie ta procedura była wyłączną, jaką stosowano do roku 1880, czyli do ogłoszenia przez Kongregację Biskupów i Zakonników Instrukcji na temat postępowania w sprawach dyscyplinarnych i karnych duchownych ${ }^{16}$.

Cavenda familiaritas cum aliqua persona vel familia, czyli zażyłość z określoną osobą lub rodziną, której należało unikać, stanowiła w myśl dekretu Maxima cura $^{17}$ z 20 sierpnia 1910 r. jedną z przyczyn uzasadniających administracyjne

${ }^{14}$ Jest to skrócona, lecz powszechnie przyjęta nazwa. Pełna nazwa kongregacji Sacra Congregatio Negotiis et Consultationibus Episcoporum et Regularium Praeposita była wynikiem połączenia przez papieża Klemensa VIII (1592-1605) w 1601 r. powołanej przez Sykstusa V Kongregacji Udzielania Porad Zakonnikom (Sacra Congregatio super Consultationibus Regularium) i stworzonej przez Grzegorza XIII (1572-1585) Kongregacji Udzielania Porad Biskupom (Sacra Congregatio super Consultationibus Episcoporum). Szerzej na temat historii kongregacji zob. E. Sztafrowski, op. cit., s. 131-140; J. Wroceński, Kongregacja Zakonów i Instytutów świeckich $w$ aspekcie historyczno-prawnym, „Prawo Kanoniczne” 1986, nr 3-4, s. 209-231.

${ }^{15}$ Zob. S.C.Ep. et Reg., Bambergen., 17 sierpnia 1883 r., [w:] Fontes, t. 4, n. 2009, s. 1031-1034.

${ }^{16}$ Zob. Instructio S.C.Ep. et Reg. z 11 czerwca 1880 r. Wprowadzała ona możliwość zastosowania postępowania sumarycznego w sytuacji, gdy nie było z jakiś powodów możliwości wszczęcia procedury sądowej. Szerzej na temat regulacji zawartych w Instrukcji zob. J. Łukowski, Procedura sądowo-kościelna podług nowej Instrukcyi św. Kongregacyi Biskupów i Zakonników, Lwów 1881; F. Droste, Canonical Procedure in Disciplinary and Criminal Cases of Clerics. A Systematic Commentary on "Instructio S.C.Ep. et Reg., 1880", New York 1887.

${ }^{17}$ Zob. „Acta Apostolicae Sedis” 1910, nr 2, s. 638. 
przeniesienie proboszcza (kan. 1, n. 9). Dochodziło do niego w szczególności w braku posłuszeństwa biskupowi, gdy duchowny ośmielał się trwać w konkubinacie z jakąś kobietą.

\section{Wyjaśnienia odnoszące się do wiernych świeckich}

Jedną $\mathrm{z}$ pierwszych kwestii $\mathrm{w}$ przedmiocie przestępstwa konkubinatu popełnionego przez świeckich, którą zajęła się Kongregacja Soboru stanowiła interpretacja przepisu zamieszczonego $\mathrm{w}$ rozdziale 8 sesji XXIV soboru trydenckiego, w myśl którego przełożony kościelny przed aplikacją kary był obowiązany udzielić trzykrotnego upomnienia osobom pozostającym in concubinatu. Problem konieczności wystosowania trzech kolejnych upomnień został podniesiony przez Henricusa Cardosusa, działającego w imieniu arcybiskupa Bragi, który zwrócił się o wyjaśnienie do wspomnianej kongregacji. Przede wszystkim pytał on czy stosownie do tego, co zostało postanowione na sesji XXIV w rozdziale 8 Tridentinum zarówno wobec konkubentów stanu wolnego, jak i związanych węzłem małżeńskim, należy zachować trzy upomnienia przed wymierzeniem kary kanonicznej i czy należy czekać na zerwanie grzesznego pożycia przez okres jednego roku, zanim wymierzy się karę ekskomuniki? ${ }^{18}$ W nadesłanej odpowiedzi kongregacja stwierdziła, iż potrójne upomnienie nie jest konieczne, chyba że została wdrożona przeciwko określonym osobom procedura zmierzająca do ich ekskomunikowania. Uznała również, że nie trzeba czekać przez jeden rok z wymierzeniem kary ekskomuniki, jeżeli nie nastąpiła poprawa życia wiernych po ich trzecim napomnieniu ze strony duchownego (trinam monitionem non esse necessariam, nisi quando proceditur ad excommunicationem. Nec annum excommunicationis expectandum $)^{19}$.

W roku 1587 wpłynęło do wspomnianej kongregacji zapytanie, skierowane przez biskupa z Vintimille, następującej treści: Czy przeciwko poszczególnym konkubentom, o których jest mowa w przepisie rozdziału 8 sesji XXIV soboru trydenckiego można wszcząć postępowanie zmierzające do wymierzenia kary po wydaniu nakazu zawierającego potrójne upomnienie kanoniczne, czy też

${ }^{18}$ Zob. S.C.C., Bracharen., listopad 1586 r., [w:] Fontes, t. 5, n. 2165: Utrum illud quod disponitur in dicto capite 8, sess. 24 dicti Concilii circa concubinarios, tam solutos, quam uxoratos ter monendos, praescribat formam. Itaque eam teneantur iudices ecclesiastici omnino observare in foro contentioso, ut ante trinam monitionem eos ratione concubinatus non possint punire, et an expectandus sit annus excommunicationis, qua feriri iubentur ibi, antequam puniantur, s. 134.

${ }_{19}$ Ibidem, s. 134. Szerzej na temat procedury dokonywania upomnień kanonicznych zob. J. N. Opieliński, O cenzurach kościelnych, Poznań 1894, s. 41-45. 
winne one być udzielane oddzielnie ${ }^{20}$. Kongregacja Soboru wyjaśniła, że nie można rozpocząć procedury zmierzającej do ukarania określonych osób bez wcześniejszego wystosowania do nich trzech oddzielnych upomnień (Non posse sed trinam monitionem separatim esse necessariam) ${ }^{21}$. Znana jest również wypowiedź Kongregacji Soboru z dnia 23 grudnia 1630 r. ${ }^{22}$, w której wyjaśnia ona arcybiskupowi $\mathrm{z}$ Rosano, że przepisy dotyczące postępowania $\mathrm{w}$ sprawie wymierzania kar zawartych $\mathrm{w}$ rozdziale 8 Tridentinum mogą być aplikowane zarówno gdy chodzi o ekskomunikę, jak i inne kary, przewidziane w prawie powszechnym Kościoła katolickiego.

A. Barbosa relacjonując przywoływane przepisy soboru trydenckiego zwrócił uwagę na fakt, że trzykrotne upomnienie konkubentów było konieczne tylko wówczas, gdy biskup zamierzał ukarać ich ekskomuniką w postępowaniu sądowym ${ }^{23}$. Natomiast, gdy o chodzi o karę pieniężną (poena pecuniaria) i inne sankcje przewidziane przez ustawodawstwo synodalne, sędzia mógł je nałożyć bez wspomnianych uroczystych napomnień. Powyższy pogląd podzielał także L. Ferraris ${ }^{24}$. Kanonista ten zaznacza wyraźnie, iż mogły to być nawet kary w postaci uwięzienia sprawcy przestępstwa (poena carceris, incarceratio), chłosty (poena fustigationis) i inne tego rodzaju ${ }^{25}$.

Inną wątpliwością powstałą $\mathrm{w}$ związku ze wspomnianym rozdziałem 8 sesji XXIV soboru trydenckiego, którą rozstrzygnęła Kongregacja Soboru była kwestia czy w stosunku do wszystkich konkubentów mogą być nakładane tym samym wyrokiem również sankcje karne ustanowione w prawie powszechnym przed soborem trydenckim oraz statutach synodalnych, czy też należy

${ }^{20}$ Zob. S.C.C., Ventimilien., grudzień 1587 r., [w:] Fontes, t. 5, n. 2194: An contra singulares concubinarios ex praescriptione c. 8 , sess. 24 , de refor. possit procedi uno praecepto peremptorio continente trinam monitionem, vel ter separatim moneri debeant, et an illud caput intelligatur cumulative quoad poenas, vel restrictive ad solam excommunicationem, et alia, et an contenti in dicto capite puniri possint de fornicatione ac concubinatu poenis arbitraries vel taxatis a iure, nisi postquam ter moniti fuerint, s. 152.

${ }^{21}$ Ibidem, s. 152.

${ }_{22}$ Zob. S.C.C., Rossanen., 23 grudnia 1630 r., [w:] Fontes, t. 5, n. 2528: Contra concubinarios procedere posse tam ad poenam excommunicationis, servata forma Concilii, c. 8, sess. 24, de ref. matrim., quam etiam ad alias poenas iure communi inflictas, s. 263.

${ }^{23}$ A. Barbosa, Sacrosancti Concilii Tridentini Canones et Decreta, item Declarationes cardinalium Concilii interpretum; ex ultima recognitione Ioan. Gallemart. cum citationibus Ioannis Sotealli nec non Remmissionibus P. Augustini Barbosa, Coloniae Agrippinae 1620, s. 405-406.

${ }^{24}$ L. Ferraris, Prompta Bibliotheca Canonica, Iuridica, Moralis, Theologica, nec non Ascetica, Polemica, Rubricistica, Historica, t. 7, Venetiis 1772, s.v. poena, art. 2, n. 76, s. 78.

${ }^{25}$ L. Ferraris, op. cit., t. 7, Venetiis 1772 , s.v. poena, art. 2, n. 77, s. 78. O możliwości uwięzienia konkubenta wzmiankuje także L. Engel, Collegium Universi Iuris Canonici, Salisburgi 1722, s. 483 oraz I. Devoti, Institutionum Canonicarum Libri IV, Bassani 1834, t. 4, s. 102-103. Szerzej o tej karze zob. A Reiffenstuel, Ius canonicum universum, t. 5, tit. XXXVII, n. 107-111, Venetiis 1715, s. 316-317. 
stosować wyłącznie kary przewidziane w omawianym rozdziale ${ }^{26}$. Kongregacja wyjaśniła, że stosowny dekret soborowy nie zniósł innych kar przewidzianych w prawie kanonicznym lub statutach synodalnych ani sposobów postępowania zmierzających do ich wymierzenia $\mathrm{z}$ wyjątkiem ekskomuniki, do nałożenia której konieczne było zachowanie procedury przepisanej we wspomnianym dekrecie ${ }^{27}$.

W roku 1639 Kongregacja Soboru na wątpliwość, czyjej jurysdykcji podlega rozpatrywanie spraw dotyczących przestępstwa konkubinatu i nierządu odpowiedziała, iż są one zaliczane do przestępstw mieszanych (delicta mixti fori $)^{28}$. Dlatego też, zdaniem kanonistów przedkodeksowych: A. Barbosy ${ }^{29}$, A. Reiffenstuela ${ }^{30}$ i L. Ferrarisa ${ }^{31}$, możliwa była penalizacja konkubentów zarówno na forum świeckim, jak i kanonicznym. W praktyce oznaczało to, że rozpoznanie sprawy przez sąd świecki nie pozbawiało Kościoła możliwości zastosowania w stosunku do winnego odpowiednich sankcji kanonicznych. Jak trafnie zauważa L. Ferraris ${ }^{32}$, działania podejmowane przez sędziego świeckiego miały jedynie na celu niepozostawienie przestępstwa bezkarnym. Głównym zaś motywem kroków przedsiębranych przez sędziego kościelnego była poprawa obyczajów konkubentów, niezbędna do zbawienia ich dusz.

W kontekście omawianej problematyki na uwagę zasługuje także wypowiedź Kongregacji Powszechnej Inkwizycji (Congregatio Sanctae Inquisitionis, Sancta Romana et Universalis Inquisitio $)^{33}$ obradującej pod przewodnictwem papieża

${ }^{26}$ Zob. S.C.C., Toletana, sierpień 1589 r., [w:] Fontes, t. 5, n. 2214: An simul et eadem sententia possint puniri praefati concubinarii soluti et uxorati aiure canonico ante Concilium Tridentinum statutis, et poena quam inflixit dictum Concilium, vel an necessario primum imponenda sit poena expressa a Concilio Tridentino, s. 163.

${ }^{27}$ Ibidem, s. 163.

${ }^{28}$ Zob. S.C.C., Reatina, 24 września 1639 r., [w:] Fontes, t. 5, n. 2611: Sacra, etc. Respondit causas concubinatus et fornicationis esse mixti fori, ideo illarum cognitionem spectare ad Iudicem, qui praevenit, hoc tamen insinuetur oretenus, s. 285.

${ }^{29}$ A. Barbosa, op. cit., s. 406.

${ }^{30}$ A. Reiffenstuel, op. cit., t. 5, tit. XVI, n. 62, Venetiis 1715, s. 224-225.

${ }^{31}$ L. Ferraris, op. cit., t. 7, Venetiis 1772, s.v. poena, art. 2, n. 78, s. 78.

${ }^{32}$ Ibidem, n. 79: Unde saecularis concubinarius punitus de hoc crimine a iudice laico, potest iterum puniri ab ecclesiastico, et sic vice versa, quia iudex laicus procedit ad solam punitionem huius delicti, ne crimina maneant impunita, ecclesiasticus autem procedit ad correctionem morum pro salute animae, s. 78.

${ }^{33}$ Nazwę tą otrzymała kongregacja na mocy konstytucji papieża Sykstusa V (1585-1590) Immensa aeterni Dei z 22 stycznia 1588 r. Papież Pius X (1903-1914) konstytucją Sapienti consilio z 29 czerwca 1908 r. przemianował ją na Kongregację Świętego Oficjum (Sacra Congregatio Sancti Officii). Obecna nazwa Kongregacja do Spraw Nauki Wiary (Sacra Congregatio pro Doctrina Fidei) jest wynikiem ogłoszenia w dniu 7 grudnia 1965 r. przez papieża Pawła VI (1963-1978) motu proprio Integrae servandae. Szerzej na temat historii kongregacji zob. E. Sztafrowski, op. cit., s. 45-65. 
Aleksandra VII (1655-1667). W dekrecie z dnia 18 marca 1666 r. ${ }^{34}$ uznała ona za godną potępienia propozycję zamieszczoną w punkcie 41, ujętą w zdanie: „Ten, kto żyje w nieślubnym związku nie ma obowiązku oddalenia swojej konkubiny, jeżeli tylko sprawuje ona nad nim niezbędną opiekę, a gdyby jej zabrakło konkubent prowadziłby życie w chorobie, inna kuchnia wzbudzałaby w nim wstręt, a ponadto trudno byłoby mu znaleźć inną opiekunkę". Z powyższego wynikało, że od moralnej powinności oddalenia konkubiny nie zwalniały żadne tego rodzaju okoliczności ${ }^{35}$.

Kolejne wyjaśnienia łączące się z kwestią konkubinatu świeckich zawiera encyklika papieża Benedykta XIV Inter omnigenas ${ }^{36}$, wydana w dniu 2 lutego 1744 r. Papież zakazał w niej przystępowania do sakramentów świętych chrześcijankom uprowadzonym przez Turków, jak również kobietom zaślubionym pod przymusem lub w młodości, ponieważ te, nie będąc złączone żadnym prawnym węzłem sakramentalnym wiary, pozostawały $\mathrm{z}$ niewiernymi $\mathrm{w}$ niegodziwym konkubinacie (in illicito concubinatu). Utrzymał tym samym w mocy wszystkie regulacje powzięte na synodzie w Albano. Odnosiły się one również do wszystkich kobiet dopuszczających się nierządu i pozostających w konkubinacie, chociaż o ich sytuacji nie decydowały wymienione wcześniej okoliczności. Kapłanom zabronił zaś udzielania im, jako niegodnym, sakramentów świętych.

Problematykę udzielania Komunii Świętej wiernym pozostającym w konkubinacie Benedykt XIV poruszył także w encyklice Ex omnibus ${ }^{37}$ z 16 października $1756 \mathrm{r}$.

W związku z podobną sytuacją do opisanej powyżej, Kongregacja Powszechnej Inkwizycji udzieliła w dniu 29 kwietnia 1891 r. łagodniejszej odpowiedzi wikariuszowi apostolskiemu w Pekinie. Podstawy do jej wydania dostarczyła wzmianka uczyniona w jego liście o wstawianiu się przez misjonarzy za młodymi chrześcijankami wydanymi wbrew ich woli za mąż za pogan, bez uzyskania

${ }^{34}$ Zob. S.C.S.Off., decr. 18 marca 1666 r., [w:] Fontes, t. 4, n. $735 \$ 1$ pkt 41: Non est obligandus concubinarius ad eiiciendam concubinam, si haec nimis utilis esset ad oblectamentum concubinarii, vulgo regalo, dum, deficiente illa, nimis aegre ageret vitam, et aliae epulae taedio magno concubinarium afficerent, et alia famula nimis difficile inveniretur, s. 20.

${ }^{35}$ H. Busenbaum, Medulla Theologiae Moralis, Coloniae Agrippinae 1678, s. 184; L. Ferraris, op. cit., t. 1, Venetiis 1772, s.v. absolutio, art. 2, n. 11-12, s. 19.

${ }^{36}$ Zob. Benedictus XIV, ep. encycl. Inter omnigenas, 2 lutego 1744 r., [w:] Fontes, t. 1, n. $339 \$ 13$ : De Mulieribus autem Christianis a Turcis per vim raptis, iisdemque violenter, vel in pueritia nuptis, quae nullo Sacramentalis fidei iure coniunctae, in illicito concubinatu cum Infidelibus perseverant, idem omnino statuimus, quod in praedicto Concilio Albano decretum fuit..., s. 806-807.

${ }^{37}$ Zob. Benedictus XIV, ep. encycl., Ex omnibus, 16 października 1756 r., [w:] Fontes, t. 2, n. 441 $\$ \$ 4-5$, s. 536. Szerzej na temat skutków pozostawania w konkubinacie w sferze kościelnego prawa sakramentalnego zob. W. Jaskulski, Concubinarius na łożu śmiertelnem, „Przegląd Kościelny” 1884/1885, $\mathrm{nr}$ 6, s. 364-365; idem, Udzielanie ostatnich sakramentów śmiertelnie chorym konkubinariuszom, „Przegląd Kościelny" 1890, nr 12, s. 702-708. 
dyspensy ze strony Kościoła ${ }^{38}$. Biorąc pod uwagę taką sytuację, kongregacja zezwoliła na udzielanie sakramentów świętych takim osobom (iuvenes et puellae), jeżeli tylko ustało względem nich bliskie niebezpieczeństwo zgorszenia i nierządu oraz pod warunkiem, że będą one miały właściwą dyspozycję duchową (dummodo utrumque periculum perversionis et fornicationis de proximo fiat remotum).

Warto $\mathrm{w}$ tym miejscu wspomnieć, że o skutkach prawnych trwania w konkubinacie na gruncie małżeńskiego prawa kanonicznego wzmiankuje papież Benedykt XIV w encyklice Satis Vobis ${ }^{39}$ ogłoszonej w dniu 17 listopada $1741 \mathrm{r}$. Podaje $\mathrm{w}$ niej przykład pozostawania in occulto concubinatu przez wiernych, postrzeganych w oczach opinii publicznej za żyjących w prawym małżeństwie, jako uzasadniony powód do tego, by wspomniane osoby mogły zawrzeć tajne małżeństwo nie narażając się na niesławę, do jakiej mogłoby dojść na skutek publicznej ceremonii małżeńskiej ${ }^{40}$. Jak widać z powyższego przykładu, Kościół nie ograniczał się jedynie do nakładania kar kanonicznych na wiernych trwających w konkubinacie. Podejmował także działania mające zachęcić takie osoby do uregulowania ich sytuacji, zgodnie z głoszoną przez siebie nauką, uwzględniając czasami niezwykle złożone okoliczności powodujące taki stan rzeczy. Potwierdzenie takiego stanowiska najwyższych władz kościelnych znajdujemy w Instrukcji wydanej 9 maja 1877 r. przez Kongregację Rozkrzewiania Wiary (Sacra Congregatio de Propaganda Fide) ${ }^{41}$, w której niebezpieczeństwo kazirodczego konkubinatu (periculum incestuosi concubinatus) oraz zniesienie publicznego konkubinatu (cessatio publici concubinatus) wymienione zostały jako kanoniczne przyczyny uprawniające wiernych do starania się o dyspensę do zawarcia małżeństwa. W obydwu przypadkach udzielenie dyspensy pozwalało uniknąć kar spadających na konkubentów, jak również zapobiegało publicznemu zgorszeniu (scandalum) wspólnoty wierzących ${ }^{42}$.

${ }^{38}$ Zob. S.C.S.Off., (Pekin.), 29 kwietnia 1891 r., [w:] Fontes, t. 4, n. 1134, s. 460-461.

${ }^{39}$ Zob. Benedictus XIV, ep. encycl., Satis Vobis, 17 listopada 1741 r., [w:] Fontes, t. 1, n. $319 \$ 6$, s. 703.

${ }^{40}$ Szerzej na ten temat zob. V. P. Coburn, Marriages of conscience, Washington 1944, s. 39-41.

${ }^{41}$ Nazwę tą otrzymała na mocy bulli Inscrutabili divinae providentiae z 22 czerwca $1622 \mathrm{r}$. papieża Grzegorza XV (1621-1623). Obecna nazwa to Kongregacja Ewangelizacji Narodów czyli Rozkrzewiania Wiary (Sacra Congregatio pro Gentium Evangelizatione seu de Propaganda Fide). Zob. także R. Skowronek, Kongregacja Ewangelizowania Narodów w rozwoju historyczno-prawnym, „Prawo Kanoniczne” 1973, nr 3-4, s. 191-207; E. Sztafrowski, op. cit., s. 149-164.

${ }^{42}$ Zob. S. C. de Prop. Fide, Instructio, 9 maja 1877 r., [w:] Fontes, t. 5, n. 2099, s. 712. Przypadki te omawia szczegółowo W. A. O’Mara, Canonical Causes for Matrimonial Dispensations, Washington 1935, s. 121-122 oraz 127-128. Przykładowe formuły podaje J. Łukowski, Instrukcja w sprawie dyspens matżeńskich ogłoszona przez św. Kongregacyą de Propaganda Fide, Poznań 1880, s. 16. 


\section{Wnioski}

Przeprowadzona analiza źródeł i poglądów doktryny kościelnej pokazuje, że uchwalone na sesjach XXIV i XXV soboru trydenckiego przepisy, według których należało penalizować konkubinat wiernych świeckich i duchownych, rodziły największe wątpliwości odnośnie do samej procedury ich stosowania. Stąd w konstytucjach papieskich i aktach normatywnych kongregacji rzymskich oraz w wydanych przez Kongregację Biskupów i Zakonników dekretach karnych, rozstrzygających poszczególne sprawy przeciwko konkubentom, pierwszorzędne miejsce zajmowały uwagi wyjaśniające sposób postępowania przy wymierzaniu kar za trwanie w konkubinacie. Sporo miejsca poświęcono także konsekwencjom natury prawnej, jakie wywoływało pozostawanie w tym grzesznym związku na polu kanonicznego prawa małżeńskiego. Nie ulega wątpliwości, że wspomniane wyjaśnienia kongregacji i wypowiedzi papieży potrydenckich miały ogromne znaczenie praktyczne, a ponadto przyczyniały się do jednolitej wykładni odnośnych postanowień soborowych $\mathrm{w}$ tej materii. Wiele $\mathrm{z}$ omawianych norm znalazło się następnie w Kodeksie Prawa Kanonicznego z 1917 r. ${ }^{43}$ 